\title{
Introduction to farming in the Central Canterbury area
}

ROY N. EVANS

Farm Consultant and Rural Valuer, Ashburton

\section{Where are we?}

On the east side of the Southern Alps of the South Island lies the province of Canterbury. Within this province there are five district regions, North, Central, Mid, and South Canterbury (all running from the mountains to the sea and separated by major rivers), and Banks Peninsula. Central and Mid Canterbury are home to the Selwyn and Ashburton District Councils (respectively) and sit side by side in the centre of Canterbury.

Selwyn District has a northern boundary with the Waimakariri River, Christchurch City, and Banks Peninsula. Ashburton District has a southern boundary with the Rangitata River. The mighty braided Rakaia River is the dividing boundary between the two districts. Canterbury Regional Council (ECAN), based in Christchurch, has control over environmental issues in the area.

\section{How big are we?}

It is $150 \mathrm{~km}$ from the main divide of the Southern Alps to the sea (the Pacific Ocean). The plains portion of this area is $50 \mathrm{~km}$ wide. The Selwyn district occupies 649000 ha and the Ashburton district 617500 ha, a total of 1266500 ha, or $4.7 \%$ of New Zealand's land mass. Approximately $50-55 \%$ of the total area is flat. (The Canterbury province in total has the largest area of flat land in New Zealand.)

\section{Population (2001 Statistics)}

The Ashburton District population is 25000 and the Selwyn District is 28000 , a total population of 53000 . Most of the population live in the rural areas.

The main rural service centers are the towns of Ashburton (pop. 14500), Darfield (pop. 1400) and Leeston (pop. 1200).

\section{History}

circa 1300

Maori settlers arrived from the Pacific Islands. Later Ngai Tahu Maori came down from the North Island and conquered and intermarried with the pre-existing Maori tribes.

1840's

Bishop Selwyn was one of the first Europeans in Central Canterbury. The Selwyn district is named after him.

1850 's

The first ships of settlers arrived from England. The rural area was first settled as sheep grazing runs producing wool. The limited water supplies on the Plains often determined the size and shape of the grazing runs, and the placing of homesteads. 1858

Ashburton's town was established. The town and district is named after Lord Ashburton, a prominent member of the New Zealand Company which purchased much of the land in the South Island.

\section{0}

By 1860 most of the High Country was now farmed on perpetual Crown leases.

1864

Cobb \& Company coaches commence service. 1866

Cropping began throughout the Plains. 1867

Stock water race development began. 1870's

The historic Long Beach Station of 12000 hectares on the Canterbury Plains south of Ashburton was being cultivated with 390 horsepower (65 six horse teams!). 1871

Canterbury Flour Mill opened, increasing the area of wheat sown.

1876

The railway reached Ashburton from Christchurch. 1878

Lincoln Agricultural College (now Lincoln University) was established.

1880

190000 hectares of crop in the area (compared to 127000 hectares in 2002).

1883

First frozen meat shipment. 1899

Freezing works opened at Fairfield near Ashburton. 1920-1930's

The Depression encouraged more wheat to be grown (100000 hectares).

1930's

The Rangitata Diversion Race built for irrigation and power generation was completed. 1944

Ashburton Lyndhurst border dyke irrigation scheme opened (26000 hectares).

Post WWII

Sheep numbers increase $8 \%$ per year. 


\section{0's}

Cropping declined over this decade.

1960's

Sheep and crop production increased.

1970's

Farm production static

1990

Removal of farm subsidies and the floating of farm loan interest rates causes a number of farmers to exit farming. Land prices fall and all development ceases as farmers retrenched into survival mode.

1990's onward

Production increases from irrigation, plant breeding, and new agrichemicals. Large scale dairy farms established throughout the region on irrigated land.

More recent farming 'milestones' include - deeper irrigation wells, many travelling irrigators of varying designs, Glyphosphate herbicide (e.g. Roundup), Strobilurin fungicides (e.g. Amistar), Sulphonyl urea herbicides (e.g. Glean), Cyclohexadione growth regulator (e.g. Moddus), farm amalgamation and bigger agricultural plant and machinery.

\section{Topography, soils and vegetation (an overview)}

The Mountains and Upland Valleys: Altitude 10002000m. A mix of permanent snow cover, exposed rock, tussock grassland and bush. Very little of this area is farmed.

The High Country, valleys and river flats: Altitude 500-1000m. Upland and High Country Yellow-Brown earth soils, (steep, erosion prone, poor fertility). Limited areas of recent (often shallow) stony soils on the flat valley floors. Tussock grassland, scrub and bush remnants, some flats cultivated. Hills often oversown and topdressed to $1000 \mathrm{~m}$ altitude.

The Foothills: Altitude 400-500m. Lowland YellowBrown earth soils on steep and rolling hills, terraces and fans. Tussock grassland at higher altitudes, oversown and topdressed hills, cultivated downs and flats, some bush remnants in gullies.

The Plains: Altitude 500m to sea level. Largely loess formed Yellow Grey earth soils, with some localised areas of Recent, Gley and Organic soils.

Twenty-thousand hectares of shallow soils with low water holding capacity and low natural fertility, 50000 hectares of free draining cropping soils, and 30000 hectares of deeper higher water table soils. Some $92 \%$ of the total effective area of the plains is in cultivated pastures or crop.

\section{Climate}

Mountains - extreme weather conditions, with 3000$7000 \mathrm{~mm}$ rainfall per annum.

High country - long cold winters, strong northwest gales, $900-3000 \mathrm{~mm}$ rainfall per annum, snow falls. Winter zero to low growth period of 130-150 days.

Foothills - long winters, some snow falls, 1000$1400 \mathrm{~mm}$ rainfall.

Plains - climate varies.

High on the plains $-900 \mathrm{~mm}$ rainfall per annum, drying hot north-west winds in summer, dry autumn, however, a reasonable balance between rainfall and evapotranspiration with limited agriculture drought soil moisture deficit days. Cold frosty winters of approximately 120 days in length.

Down the plains - the climate graduates to the coast. Rainfall reduces to $650 \mathrm{~mm}$ per annum, strong drying north-west winds in summer and autumn (especially where exposed to north-west wind from the major river gorges), autumn droughts are common. Milder winters, of approximately 80 days in length.

The Plains 'text book' weather pattern rotates through cooler easterly winds, followed by north-west gales (rain in the mountains, but limited rainfall if any on the plains), followed by southerly rain (or snow in winter at higher altitudes).

Rainfall on the plains is on average evenly spread, however, the average belies the often extreme betweenmonth and between-year rainfall variability.

\section{Average annual pasture production on the plains}

Dryland - 5000 to $9000 \mathrm{~kg}$ dry matter (DM) per hectare.

Irrigated sheep grazed - 10000 to $12000 \mathrm{~kg}$ DM per hectare.

Irrigated dairy grazed - 15000 to an estimated $20000 \mathrm{~kg}$ DM per hectare.

\section{Water}

\section{(a) Background}

The district's biggest natural assets, after the flat topography and versatile soils, are the hot dry summers and autumns. These favourable seasonal weather patterns provide the dry harvest conditions that are necessary for the arable farming industry. However, the hot dry weather conditions are also a liability. These same dry conditions generate 40 plus days of soil moisture deficit (agricultural drought days) per year, limiting crop and pasture yields. Important surface water sources in the area are the major Rangitata and Rakaia rivers, and to a lesser extent the Ashburton, Hinds and Selwyn rivers. The district's rivers, (perched above the ground water table), along with rainfall run-off, and excess rainfall and excess irrigation (over and above evapotransvaporisation), also contribute water recharge to the sizeable underground aquifers on the Plains. The free draining soils on the Plains are drought 
prone and need irrigation, however, these free draining soil types are the envy of some other countries as they do not suffer from irrigation induced problems such as surface salting.

Finding new sources of water for further irrigation development in the district is now critical. Additional irrigation water (or improved reliability of the existing supply) is required to maximise existing land use options, to underpin the increasing cost of inputs required for current production levels, to maintain viability of current farm size, and also for continued economic development of the district.

If a large water storage site could be found, it is estimated that only four day's flood flow in the Rakaia River, over and above the river's Conservation Order minimum flow restriction, would supply enough irrigation water to irrigate all of the Mid Canterbury Plains for a whole season.

\section{(b) Stock water}

Although some stock water is pumped from wells, there is still a reliance on the $5600 \mathrm{~km}$ of stock water races which form a tracery across the Plains from the foothills to the sea $(3600 \mathrm{~km}$ Ashburton, $2000 \mathrm{~km}$ Selwyn).

\section{(c) Irrigation}

Water for irrigation is sourced from private and community schemes.

The Ashburton District has the largest flood irrigation scheme in New Zealand.

Early irrigation schemes were first developed in the 1930s, however, the major irrigation development of that era was the Rangitata Diversion Race (RDR). Built during the Depression, the RDR is a massive water canal travelling from an intake on the upper reaches of the Rangitata River, through two small power stations to an outlet at Highbank, on the Rakaia River. It runs 66 kilometres across the district with irrigation schemes drawing water along its entire length, enabling flood irrigation of 64000 ha. This irrigated area amounts to approximately half the 120000 hectares of irrigated agricultural land in the Ashburton District.

The RDR is a company owned by the Ashburton Lyndhurst, the Valletta, and the Mayfield irrigation schemes, the Ashburton District Council, and Trustpower, in five equal shareholdings. The irrigation water is largely border dyked (flood) irrigated, however, some farmers have changed to spray irrigation systems sourced from their water allocation within the schemes.

The largest area of spray irrigation in the district is sourced from wells, with a lesser amount drawn direct from rivers or drains. Irrigation wells are shallow near the coast $(40 \mathrm{~m})$ and deeper as irrigation has moved further up the plains $(240 \mathrm{~m})$. Labour intensive irrigation systems (for example handshift and sideroll), have now been replaced with travelling irrigators such as rotary irrigators, travelling booms, gun irrigators, lateral booms, and centre pivots. There is also a limited use of K Line (motorbike shifted independent sprinklers) irrigation on farms in small areas unable to be reached (or unsuited) to large travelling irrigators.

Average evapotranspiration (soil moisture loss) in December and January on the Plains is 3.9 to 4.2 $\mathrm{mm}$ per day, with extremes under cropping up to $6 \mathrm{~mm}$ a day.

Irrigation development across the area has meant not only intensification of existing crop and stock systems, and the arrival of new crop varieties, but an opportunity for new farm enterprises, including horticulture field crops such as bulbs, carrots, onions and sweetcorn, and an expanding dairy farm industry. Some crop types are now only made available by agents to those farmers with irrigation. A large percentage of farms on shallow soil types are now totally dependent on irrigation.

This area was once called 'The Granary of New Zealand'. I consider it is now the 'Irrigation Centre' of New Zealand.

Two large co-operative irrigation schemes are still under investigation on the Plains. They are the Barhill scheme with a potential to irrigate 40000 ha, and the Central Canterbury scheme with a 84000 ha potential.

Current constraints to the wholesale adoption of new community irrigation schemes are: the procurement of Resource Management Consents, the capital cost of new innovative water delivery and storage systems, and the problems of farmers being very supportive (with capital contributions) initially, but with a mix of personal and farm financial positions hindering final commitment en masse, that is required to make up a relatively continuous land area necessary for viable schemes.

Wider community, economic, environmental, and social benefits from irrigation will need to be examined and publicised in future to encourage joint participation and financing by Central, Regional or District government (as often occurred in the past).

\section{Farming systems}

The High Country: Extensive properties farming sheep and breeding cattle on the steep hills, grazing the higher altitudes only in the summer. Farm products sold include wool, store and prime lambs, and store cattle. 
Breeds are Merino, Half Bred and Cross Bred sheep and Angus and Hereford cows. Deer are often farmed on the lower slopes and flats. The average High Country Run size is $8000-10000$ hectares.

The Foothills: Farming includes semi-intensive breeding and fattening of sheep and cattle, selling wool and store or prime lambs and store or finished cattle. There are deer farms on the hills and flats.

\section{The Plains}

(a) Stock farming - intensive sheep breeding (wool and prime lambs), lamb trading, cattle fattening, specialist bull beef, dairying, dairy heifer grazing, large areas of dairy winter feed grazing, intensive deer breeding and finishing, beef feed lot (50 ha, 15000 head capacity), pigs (3rd largest pork production in New Zealand), horse training.

(b) mixed farming (sheep and crop) and intensive cropping - wheat (milling, biscuit, purple, pasta, feed etc), barley (feed and malting), triticale, oats, ryecorn, field peas (brown, blue, white, marrowfat, and garden varieties), process peas, lentils, buckwheat, chinese brassica, radish, sprouting radish, phacellia, borage, lily bulbs, onions, potatoes (process, seed and table), oilseed rape, forage brassica seed crops, trefoil, lotus, chicory, plantain, perennial grass seed (forage and turf), annual grass seed, fescue grass seed, brome grass seed, white clover seed, red clover seed, spinach, corn salad, coriander, mustard, carrots (seed and vegetable), maize (silage and grain), specialist cereal and grass silage crops, linseed, blackcurrants, grapes and nurseries. Other niche crops also include yarrow, squash, evening primrose and asparagus.

Valuable crop by-products sold for stock feed include grass seed straw, cereal straw and pea straw.

The Ashburton District produces approximately 50\% of New Zealand's grain and $60 \%$ of the small seed production.

Winter and summer forage crops grown include swede, turnip, kale, rape, fodder radish, greenfeed oats, greenfeed ryecorn, greenfeed triticale and annual ryegrasses.

Pastures are generally ryegrass based, mostly sown from certified seed with an estimated $50 \%$ being proprietary seed. Pasture species sown include long, medium, and short term types.

Pasture longevity in the foothills and on irrigated dairy farms is an estimated 10-15 years. In mixed sheep cropping systems it is 2-4 years.

\section{Our Grasslands people}

These include academics, scientists, farm consultants, farmers, financiers, seed dressers, grain and seed agents, seed certifiers, fertiliser and agrichemical reps.

\section{Our Centres of Grassland Research}

These include Lincoln University, AgResearch Lincoln, Crop and Food Research Lincoln, Landcare, Foundation for Arable Research (FAR), Kimihia (Wrightson), Ceres (Pyne Gould Guinness), Cropmark, Agricom, Agriseeds and Midlands Seeds.

\section{A typical farm overview}

\section{(a) Farm 1 - Foothills area}

Topography

flat

Altitude

Rainfall

Irrigation

Soil type

Farm type

Farmer type

Farm property value

Total farm capital

Gross income

Farm working expenditure

Farm operating surplus

$400 \mathrm{~m}$

$1050 \mathrm{~mm}$ per annum

no

Ruapuna stony silt loam (free draining and stony) intensive sheep, bull beef and deer early adopter, analytical, monitoring

$\$ 1900000$ (\$9000/ha) (\$700 per SU)

$\$ 2300000$

$\$ 800 /$ ha

$\$ 500 /$ ha

\$300/ha (before personal, debt servicing and capital expenditure or depreciation).

\section{Herbage issues}

- pasture longevity (new species persistence, weed invasion, off type reversion, grass grub, porina caterpillar)

- lack of research on medium and long term pasture dynamics and persistence

- anecdotal evidence versus factual advertising

- misleading use of research results in advertising

- integrity of reported trial results

- cost of new proprietary seed

- independence of herbage advisers

- the difficulty in making on-farm herbage comparisons

- white clover persistence in pastures

- information dissemination (not specialised enough?)

- suitability of overseas bred varieties to local conditions

- in excess of 30 perennial and long rotation ryegrasses to choose from (he only has eight toothpaste varieties to choose from!)

\section{(b) Farm 2 - Mid Plains}

Topography

flat

Altitude 


\begin{tabular}{|c|c|}
\hline Rainfall & $900 \mathrm{~mm}$ per annum \\
\hline Irrigation & $\begin{array}{l}\text { spray irrigated (four } \\
\text { irrigators) }\end{array}$ \\
\hline Soil type & $\begin{array}{l}\text { Mayfield and Wakanui } \\
\text { silt loam }\end{array}$ \\
\hline Farm type & $\begin{array}{l}\text { intensive, cropping, } \\
\text { sheep and winter lamb } \\
\text { trading }\end{array}$ \\
\hline Farmer type & $\begin{array}{l}\text { early adopters, enjoy } \\
\text { machinery and the } \\
\text { complexity of the mixed } \\
\text { sheep and crop farming } \\
\text { system }\end{array}$ \\
\hline Farm property value & $\$ 5500000(\$ 11900 / \mathrm{ha})$ \\
\hline Total farm capital & $\begin{array}{l}\$ 7200000 \text { (land, stock, } \\
\text { plant etc) }\end{array}$ \\
\hline Gross income & $\$ 2200 /$ ha \\
\hline Farm working expenditure & $\$ 1500 /$ ha \\
\hline Operating surplus & $\begin{array}{l}\$ 700 / \text { ha (before wages of } \\
\text { management, debt ser- } \\
\text { vicing and capital } \\
\text { expenditure or depreci- } \\
\text { ation) }\end{array}$ \\
\hline
\end{tabular}

\section{Herbage issues}

- seed yield of new varieties

- price received by the grower

- high cost, and (relatively) high risk of production

- irrigation water efficiency

- matching nitrogen input to demand

- minimising agrichemical use

- arable plant replacement and running costs

- fungicide resistance
- crop insurance costs

- future irrigation limitations (Canterbury Regional Council have publicly notified that several Canterbury areas now have $100 \%$ allocation of ground water irrigation abstraction)

- pressure to grow the business to enable economies of scale

- having to pay (over and above royalty payment) to buy back own produced seed for own pasture use

- herbage production appears to be the only industry where the producer (grower) pays for the retailer's packaging

\section{Conclusion}

The Selwyn and Ashburton Districts in Canterbury are characterised by:

- extremes of topography

- large areas of flat land

- large areas of irrigated land

- large scale production, and end use of herbage species

- incredibly diverse, intensive, and synergistic arable and stock farming systems

- centres of grasslands research

These characteristics make this area home, not only to innovative farmers, but also to a relatively high density of farm consultants, herbage scientists, and seed production personnel.

\section{ACKNOWLEDGEMENTS}

Richard Green, Lester Fletcher, Selwyn and Ashburton District Councils, AgriQuality, David Clark, Jim Chapman, John Young, Carol Fletcher. 
Appendix I Farm statistics (all of Canterbury).

\begin{tabular}{|c|c|c|c|c|}
\hline Stock numbers & 1983 & 1994 & 2002 & $\begin{array}{c}\% \text { of } \mathrm{NZ} \\
\text { stock } \\
\text { numbers }\end{array}$ \\
\hline Sheep & 11685000 & 9747000 & 7558000 & 20 \\
\hline Dairy cattle & 73000 & 212000 & 543000 & 10 \\
\hline Beef cattle & 285000 & 453000 & 505000 & 11 \\
\hline Deer & est 44000 & 259000 & 412000 & 25 \\
\hline Crop area (ha) & 1993 & & 2002 & $\begin{array}{c}\% \text { of } \mathrm{NZ} \\
\text { crop } \\
\text { hectares }\end{array}$ \\
\hline Wheat for milling & 39767 & & 18316 & 88 \\
\hline Wheat for other use ) & & & 16945 & 79 \\
\hline Barley & 47249 & & 51567 & 66 \\
\hline Oats & 11208 & & 4631 & 63 \\
\hline Other cereals & & & 1689 & 65 \\
\hline Maize grain & & & 404 & 3 \\
\hline Seed peas & 18063 & & 8518 & 78 \\
\hline Other pulses & & & 124 & 79 \\
\hline Other crops & & & 23727 & 77 \\
\hline Total & & & 127221 & 67 \\
\hline
\end{tabular}

Sources: (1) 2002 Agriculture Production Census: Statistics New Zealand.

(2) MAF Information Services Aglink 1986.

Appendix II Farm statistics (North, Central \& Mid Canterbury).

\begin{tabular}{lcc}
\hline Area of certified seed production (ha) & $2003 / 2004$ & $\%$ of NZ \\
Arable crops & 1669 & 66 \\
Brassicas & 752 & 63 \\
Grasses herbage \& amenity & 17637 & 77 \\
Legumes (clover, Lotus etc) & 7079 & 83 \\
Other species & 460 & 60 \\
Total & 27597 & 77 \\
\hline
\end{tabular}

Source: Seed Production statistics - Agriquality New Zealand. 